\title{
Faktor-faktor yang Berhubungan dengan Kejadian Anemia pada Anak yang di Rawat Inap di RSUD Manembo-Nembo Kota Bitung
}

\author{
Fabiola V. Umboh \\ Stefanus Gunawan \\ Ari Runtunuwu
}

\author{
${ }^{1}$ Program Studi Pendidikan Dokter Fakultas Kedokteran Universitas Sam Ratulangi Manado \\ ${ }^{2}$ Bagian Ilmu Kesehatan Anak Fakultas Kedokteran Universitas Sam Ratulangi Manado \\ Email: umbohfabiola@gmail.com
}

\begin{abstract}
Anemia is one of the most common clinical problems in the medical world, either in adults or children. The impact of anemia on children can lead to physical growth disorders, low resistance to disease, less intelligence level, and less learning and sport achievement. This study was to obtain the factors related to the incidence of anemia in children at RSUD Manembo-nembo Bitung. This was an analytical descriptive study using a cross sectional design. Data were obtained from patients' medical records and questionnaires. Samples were 46 children, 28 were less than 5 years old. The results showed that there was a correlation between parent education level $(P=0.033)$ as well as socioeconomic status of the family $(P<0.001)$ to the occurrence of anemia, however, there was no correlation between nutritional status with the incidence of anemia $(P=0,244)$. Conclusion: The most influential factor to the incidence of anemia in children was the social economic status of the family.
\end{abstract}

Keywords: anemia, children, socioeconomic status

\begin{abstract}
Abstrak: Anemia merupakan salah satu masalah klinis yang sering ditemukan di dunia kedokteran baik pada orang dewasa maupun anak. Dampak anemia bagi anak dapat menyebabkan gangguan tumbuh kembang fisik, rendahnya daya tahan terhadap penyakit, tingkat kecerdasan yang kurang dari seharusnya, serta prestasi belajar dan prestasi olahraga yang rendah. Penelitian ini bertujuan untuk mengetahui factor-faktor yang berhubungan dengan kejadian anemia pada anak-anak yang dirawat di RSUD Manembo-nembo Kota Bitung. Jenis penelitian ini ialah deskriptif analitik dengan desain potong lintang. Penelitian ini menggunakan data rekam medik pasien dan hasil kuesioner. Sampel penelitian berjumlah 46 anak. Sebagian besar sampel berusia $\leq 5$ tahun dengan jumlah 28 anak. Hasil penelitian menunjukkan bahwa terdapat hubungan bermakna antara tingkat pendidikan orang tua $(P=0,033)$ dan status sosial ekonomi keluarga $(P<0,001)$ dengan kejadian anemia, sedangkan status gizi pada anak tidak berhubungan dengan kejadian anemia $(P=0,244)$. Simpulan: Faktor yang paling berpengaruh terhadap kejadian anemia pada anak yang dirawat di RSUD Manembo-nembo ialah status sosial ekonomi keluarga.
\end{abstract}

Kata kunci: anemia, anak, status sosial ekonomi

Anemia merupakan salah satu masalah klinis yang sering ditemukan di dunia kedokteran baik pada orang dewasa maupun pada anak. Anemia didefinisikan sebagai suatu penurunan jumlah sel darah merah, dan juga menunjukkan rendahnya kadar hemoglobin $(\mathrm{Hb})$, hematokrit (Hct), dan jumlah eritrosit di bawah normal. Anemia bukan suatu diagnosis melainkan suatu cerminan perubahan patofisiologi yang mendasar yang ditegakkan melalui tahapan anamnesis, pemeriksaan fisik, dan konfirmasi laboratorium. ${ }^{1}$

Anemia defisiensi besi (ADB) merupa- 
kan penyebab anemia paling banyak di seluruh dunia, terutama dinegara berkembang. Diperkirakan 4 sampai 5 milyar anak mengalami anemia defisiensi besi dan $90 \%$ terjadi di Negara sedang berkembang yang menyebabkan tingginya angka morbilitas dan mortalitas. Asian Development Bank menyatakan sekitar 22 juta anak Indonesia terkena anemia, yang menyebabkan hilangnya angka IQ 5-15 poin. Hal ini sangat mungkin dipengaruhi oleh rendahnya tingkat pengetahuan tentang nutrisi, tingkat sosial ekonomi, dan asupan gizi. ${ }^{2,3}$

Dampak anemia bagi anak ialah dapat menyebabkan gangguan tumbuh kembang fisik, rendahnya daya tahan terhadap penyakit, tingkat kecerdasan yang kurang dari seharusnya, serta prestasi belajar dan olahraga yang rendah. Selain itu, anemia pada anak akan berdampak pada menurunnya kemampuan dan konsentrasi belajar, mengganggu pertumbuhan baik sel-sel tubuh maupun sel-sel otak sehingga menimbulkan gejala wajah tampak pucat, letih, lesu, dan cepat lelah. ${ }^{4}$

World Health Organization (WHO) dalam worldwide prevalence of anemia melaporkan bahwa total keseluruhan penduduk dunia yang menderita anemia ialah 1,62 miliar dengan prevalensi pada anak sekolah dasar 25,4\% dan 305 juta anak sekolah di seluruh dunia menderita anemia. Secara global, prevalensi anemia pada anak usia sekolah menunjukkan angka yang tinggi yaitu $37 \%$, sedangkan di Thailand 13,4\% dan di India sebesar $85,5 \%$. Prevalensi anemia di kalangan anak di Asia mencapai 58,4\%; angka ini lebih tinggi dari rata-rata di Afrika $(49,8 \%){ }^{2}$ Kasus anemia di Indonesia terdapat pada $19,7 \%$ perempuan, $13,1 \%$ laki-laki, dan $9,8 \%$ anak. Sebanyak $60,2 \%$ dari anemia tersebut ialah anemia mikrositik hipokrom yang paling sering disebabkan oleh anemia defisiensi besi. $^{5}$

Berdasarkan beberapa hasil penelitian di Sulawesi Utara, prevalensi anemia pada anak sekolah usia 6-12 tahun sebesar 62,8\%. Anak kelompok usia 10-13 tahun mempunyai prevalensi anemia yang lebih tinggi $(55,17 \%)$ dari pada anak kelompok usia 6-9 tahun (33,33\%). Dari data yang diperoleh, terdapat 117 kasus anemia pada anak dari total 712 anak yang dirawat inap di RSUD Manembo-nembo Kota Bitung, yang tergabung dari golongan usia 5-13 tahun, jenis kelamin laki-laki dan perempuan, tanpa memandang tingkat pendidikan orang tua, tingkat sosial ekonomi keluarga, dan status gizi anak. ${ }^{1,4,6}$ Oleh karena tingginya prevalensi anemia di Sulawesi Utara khususnya di Kota Bitung dan sekitarnya maka diperlukan penelitian lebih lanjut untuk mengkaji faktor-faktor yang sangat berhubungan dengan kejadian anemia pada anak.

\section{METODE PENELITIAN}

Jenis penelitian ini ialah deskriptif analitik dengan desain potong lintang. Penelitian dilakukan di RSUD Manembonembo Kota Bitung selama periode bulan September-Oktober 2016.

Data penelitian diperoleh dari rekam medik pasien anak di RSUD Manembonembo Kota Bitung dan hasil kuesioner. Analisis data dilakukan dengan menggunakan computer program SPSS.

\section{HASIL PENELITIAN}

Selama periode penelitian pada bulan September-Oktober 2016 didapatkan 46 anak rawat inap di RSUD Manembonembo Kota Bitung. Dari 46 sampel penelitian, terdapat pasien laki-laki sebanyak 26 anak $(56,5 \%)$ dan perempuan sebanyak 20 anak $(43,5 \%)$ (Tabel 1).

Tabel 1. Jumlah pasien berdasarkan jenis kelamin

\begin{tabular}{ccc}
\hline Jenis kelamin & $\mathbf{N}$ & $\mathbf{\%}$ \\
\hline Laki-laki & 26 & 56,5 \\
Perempuan & 20 & 43,5 \\
Total & 46 & 100 \\
\hline
\end{tabular}

Dari 46 sampel penelitian, sebagian besar berusia $<5$ tahun dengan jumlah 28 anak $(60,9 \%)$, diikuti kelompok usia 5-10 tahun dengan jumlah 12 anak $(26,1 \%)$, dan kelompok usia $>10$ tahun dengan jumlah 6 anak (13\%) (Tabel 2). 
Hasil analisis statistik menggunakan uji Chi Square mendapatkan nilai signifikansi $P=0,033(<0,05)$ yang menunjukkan terdapat hubungan bermakna antara tingkat pendidikan orang tua khususnya ibu dan status anemia pada anak-anak yang dirawat inap di RSUD Manembo-nembo Kota Bitung (Tabel 3).

Tabel 2. Karakteristik responden berdasarkan usia

\begin{tabular}{ccc}
\hline Usia & $\mathbf{N}$ & $\mathbf{\%}$ \\
\hline$\leq 5$ tahun & 28 & 60,9 \\
$5-10$ tahun & 12 & 26,1 \\
$>10$ tahun & 6 & 13,0 \\
Total & 46 & 100 \\
\hline
\end{tabular}

Hasil analisis statistik menggunakan uji Chi Square mendapatkan nilai signi- fikansi $P=0,000(<0,05)$ dengan nilai Odds Ratio (OR) pada variabel penelitian ini ialah $\mathrm{OR}=43,87$. Hal ini berarti bahwa terdapat hubungan bermakna antara status sosial ekonomi dan status anemia pada anak-anak yang dirawat inap di RSUD Manembo-nembo Kota Bitung, dimana variabel status sosial ekonomi dapat memberikan kontribusi sebesar 43,87 kali lebih besar terhadap variabel kejadian anemia (Tabel 4).

Hasil analisis statistik menggunakan uji Chi Square mendapatkan nilai signifikansi $P=0,244(>0,05)$ yang menunjukkan tidak terdapat hubungan bermakna antara status gizi dan status anemia pada anakanak yang dirawat inap di RSUD Manembo-nembo Kota Bitung (Tabel 5).

Tabel 3. Hubungan antara tingkat pendidikan dan kejadian anemia berdasarkan hasil tabulasi silang pada anak-anak yang di rawat inap di RSUD Manembo-nembo Kota Bitung

\begin{tabular}{ccccccccc}
\hline Variabel & \multicolumn{3}{c}{ Status anemia } & \multicolumn{2}{c}{ Total } & $\boldsymbol{P}$ \\
& & \multicolumn{2}{c}{ Tidak anemia } & \multicolumn{2}{c}{ Anemia } & & & \\
& & $\mathrm{N}$ & $\%$ & $\mathrm{~N}$ & $\%$ & $\mathrm{~N}$ & $\%$ & \\
\hline Tingkat & Baik & 14 & 30,4 & 1 & 2,2 & 15 & 32,6 & \\
pendidikan & Cukup & 13 & 28,3 & 11 & 23,9 & 24 & 52,2 & 0,033 \\
& Kurang & 4 & 8,7 & 3 & 6,5 & 7 & 15,2 & \\
& Total & 31 & 67,4 & 15 & 32,6 & 46 & 100 & \\
\hline
\end{tabular}

Tabel 4. Hubungan antara sosial ekonomi dan kejadian anemia berdasarkan hasil tabulasi silang pada anak-anak yang di rawat inap di RSUD Manembo-nembo Kota Bitung

\begin{tabular}{cccccccccc}
\hline \multirow{2}{*}{ Variabel } & \multicolumn{4}{c}{ Status anemia } & \multicolumn{2}{c}{ Total } & P & OR \\
& & Tidak anemia & \multicolumn{2}{c}{ Anemia } & & & & \\
& & $N$ & $\%$ & N & $\%$ & N & $\%$ & & \\
\hline Status sosial & Cukup & 27 & 58,7 & 2 & 4,3 & 29 & 63,0 & & \\
ekonomi & Rendah & 4 & 8,7 & 13 & 28,3 & 17 & 37,0 & $<0,001$ & 43,87 \\
& Total & 31 & 67,4 & 15 & 32,6 & 46 & 100 & & \\
\hline
\end{tabular}

Tabel 5. Hubungan status gizi dan kejadian anemia berdasarkan hasil tabulasi silang pada anak-anak yang di rawat inap di RSUD Manembo-nembo Kota Bitung

\begin{tabular}{ccccccccc}
\hline Variabel & \multicolumn{3}{c}{ Status anemia } & \multicolumn{2}{c}{ Total } & P \\
& & \multicolumn{2}{c}{ Tidak anemia } & \multicolumn{2}{c}{ Anemia } & & & \\
& & $\mathrm{N}$ & $\%$ & $\mathrm{~N}$ & $\%$ & $\mathrm{~N}$ & $\%$ & \\
\hline \multirow{2}{*}{ Status gizi } & Normal & 30 & 65,2 & 13 & 28,3 & 43 & 93,5 & 0,244 \\
& Rendah & 1 & 2,2 & 2 & 4,3 & 3 & 6,5 & \\
& Total & 31 & 67,4 & 15 & 32,6 & 46 & 100 & \\
\hline
\end{tabular}




\section{BAHASAN}

Berdasarkan karakteristik dasar diperoleh hasil bahwa sebagian besar responden penelitian ialah anak-anak berusia $0-5$ tahun dengan jumlah 28 orang $(60,9 \%)$. Hasil penelitian ini memberikan gambaran bahwa golongan usia balita masih rentan terhadap masalah penyakit. Meskipun kategori sakit ringan akan tetapi bila anak rentan dan sering sakit dapat membuat orang tua merasa cemas. Penyebab anak seringkali sakit di antaranya ialah gangguan imunologik ketika lahir. Anak dengan daya tahan tubuh rendah sering mengalami infeksi sedangkan anak yang lahir normal tanpa adanya faktor bawaan bila sering sakit dapat dikarenakan infeksi kronis. Salah satunya dapat disebabkan karena melakukan kontak dengan pengidap tuberkulosis sehingga anak tertular penyakit tersebut. Selain itu dapat pula disebabkan karena faktor cuaca. Pergantian cuaca dapat menyebabkan anak dengan riwayat keluarga alergi sering mengalami pilek dan infeksi. Penyebab anak sering sakit dapat pula disebabkan karena gangguan gizi yang mengakibatkan daya tahan tubuh menjadi terganggu. ${ }^{7}$

Pada hasil pemantauan rekam medik pasien didapatkan bahwa sebagian besar diagnosis penyakit ialah observasi febris sebanyak 13 anak $(28,2 \%)$, diikuti bronkopneumonia sebanyak 6 anak $(13,1 \%)$, ganstroeneteritis akut sebanyak 5 anak $(10,8 \%)$, dan infeksi virus sebanyak 5 anak $(10,8 \%)$.

Hasil analisis univariat mendapatkan bahwa sebagian besar tingkat pendidikan orang tua khususnya ibu rumah tangga berada pada kategori cukup dengan jumlah 24 orang $(52,2 \%)$ dan kategori baik sebanyak 15 orang $(32,6 \%)$. Hasil penelitian menunjukkan bahwa tingkat pendidikan orang tua khususnya ibu rumah tangga berperan penting dalam proses pertumbuhan dan perkembangan anak. ${ }^{8}$ Hal ini dikarenakan waktu ibu di rumah bersama anak lebih besar dibandingkan ayah yang sebagian besar pekerjaannya di luar rumah.

Status sosial ekonomi keluarga yang lebih dominan berada pada kategori cukup yakni 29 keluarga (63\%). Hal ini menggambarkan bahwa sebagian besar keluarga sampel penelitian sudah termasuk dalam kategori keluarga yang cukup dalam memenuhi kebutuhan rumah tangga. Status sosial ekonomi yang baik akan berpengaruh dalam proses pemenuhan kebutuhan anak sejak dalam kandungan. Orang tua dengan status sosial ekonomi rendah tidak dapat memenuhi kebutuhan keluarga sehari-hari yang berdampak pada pertumbuhan dan perkembangan anak.

\section{SIMPULAN}

Berdasarkan hasil penelitian ini dapat disimpulkan bahwa faktor yang paling berpengaruh terhadap kejadian anemia pada anak yang di rawat inap di RSUD Manembo-nembo Kota Bitung ialah status sosial ekonomi keluarga.

Terdapat hubungan antara tingkat pendidikan orang tua dan status sosial ekonomi keluarga dengan kejadian anemia sedangkan status gizi pada anak tidak berhubungan dengan kejadian anemia.

\section{DAFTAR PUSTAKA}

1. Wijaya IK, Mantik M. Efektifitas suplementasi besi harian dibandingkan mingguan pada anemia defisiensi besi anak umur 5-11 tahun. 2008;10:129-33.

2. Dahlan MS. Statistik untuk Kedokteran dan Kesehatan. Jakarta: Salemba Medika, 2007.

3. Lestari ED. Buku Ajar Nutrisi Pediatrik dan Metabolik. Jakarta: Ikatan Dokter Anak Indonesia, 2011.

4. WHO. The world nutrition situation-nutrition throughtout the life cycle. ACC-SCN in collaboration with IFPRI; 2000.

5. Worldwide prevalence of anemia 1993-2005. Global database on anemia. WHO library cataloguing-in-publication data. Geneva: WHO, 2008.

6. Data statistik angka kasus anemia pada anak di RSUD Manembo-nembo Bitung, 2015.

7. Damayanti RS, Nasar SS, Devaera Y, Tanjung C. Asuhan Nutrisi Pediatrik. Rekomendasi Ikatan Dokter Anak Indonesia. Jakarta: IDAI, 2011.

8. Mengapa anak sering sakit ? Artikel Kesehatan Anak. Jakarta; 2016

9. Samsi F, Sunarto K. Hubungan pengetahuan 
Umboh, Gunawan, Runtunuwu: Faktor-faktor yang berhubungan dengan ...

gizi, pendidikan formal ibu rumah tangga dan keadaan sanitasi lingkungan dengan status gizi balita [Tesis].

Gorontalo: Univeristas Negeri Goron- talo. [cited 2015 Dec 30]. Available from: http://eprints.ung.ac.id/ id/eprint/ 11840 